the pate being darker, the tail black. However, there was a light flank patch which the Cinnamon does not have. On the Blue-winged Teal this patch is white; on the bird seen it was a light creamy-yellow or off-white depending on the observer. The second difference was on the face. The Cinnamon Teal's face is unmarked, whereas the bird we saw had a small white patch. This patch was less than a quarter the extent of the white crescent-shaped marking on the face of a Blue-winged Teal and was more frontally placed and not as sharply delineated as that crescent. Seen head on, both patches showed on the front of the face in line with the upper portion of the upper mandible, that is, in the region of the lores.

Wing markings were those of the two teals, which on flying birds are not separable in any event.

The bird was accompanying a female which was typical of the similar appearing Blue-winged and Cinnamon Teal females. While we were observing them, they were swimming, skip-flying and preening, movements which gave us many good views of the male.

Observing conditions were: $30-50$ yards, mid-day, overcast; $10 \mathrm{X}$ and $7 \mathrm{X}$ binoculars.

Dr. J. B. Gollop, Canadian Wildlife Service, later informed us that there are records of crossing between the two species. One that he drew to our attention was a hybrid male taken in Utah, on June 9, 1947.2 The description of the specimen is the same as for the Rice Lake bird with two exceptions: a white rather than an off-white flank patch and a full crescent face patch rather than a vestigal patch.

In the Blue Jay, 1971, Fred W. Lahrman' reported on a hybrid Cinnamon Teal-Blue-winged Teal he had photographed near Regina in 1970. We examined the transparencies on file in the Saskatchewan Museum of Natural History. The only marked difference was in the colour pattern of the body, the bird we observed being closer to the Cinnamon colouration than was the one in the Lahrman photograph. That is, the Rice Lake bird's body was a deeper chestnut. also lacked the Blue-winged Teal dark spots, marks present on th Regina bird.

'LAHRMAN, FRED W. 1971. Hybrid Cinnumo, Teal X Blue-winged Teal al Regina. Blue Jay' 2 28.

"WILSON, V. T. and J. B. VAN DENAKKEK 1948. A hybrid Cimnanon Teal-Blue-winged Ted al the Bear River Migratory Bird Refuge, Uta Auk 6.5: 316

\section{TRAGEDY IN A WREN HOUSE}

$$
\text { By C. G. RILEY* }
$$

A pair of wrens seemed to be well o the way to success in raising a family $i$ our nest house. Both adults had bee busily carrying food in. The youn were becoming vociferous, and the grotesque little heads could be seen ir side the 1 -inch entrance hole.

Then the male (?) abruptly disan peared. During the next 4 days th female (?) continued to feed the youn and then she too disappeared.

After a day of enforced listening the incessant hungry clamour, w broke down and began what we kne must be an ultimately futile progra of feeding the cluster of noisy ope mouths. Several times a day, flie dewinged moths, pieces of gardc worm, bits of ground beef, wer hungrily snatched from forceps unt appetites were seemingly satisfied $f$ the time being. Two busy days of th culminated with the cool night (4 deg. F.) of June 30 . The next mornit all was quiet.

One young bird had fallen out of th nest house the day before, and v believed we had been feeding the thr remaining ones. But when we openc the nest house we found five litt corpses, for a total brood of six. A appeared equally developed, we

\footnotetext{
* 1630 Wiggins Ave.,

Saskatoon, Saskatchewan.
} 
rovered with down, and with wing and ail feathers well developed.

What caused the tragedy? Had the arents fallen victims to cats? Had hey for some reason been forced to bandon their family? From the time he male (?) disappeared we were hewly aware of a wren singing a few houses away. Could this be our wren? unfortunately, we will never know the inswers to these questions.

Editor's Note: Six is not a large clutch for
House Wrens; Peterson's Western Bird Guide gives 5 to 8 eggs as usual with 12 as maximum. As far as is known, only the male sings. House Wrens raise two and sometimes three broods a year. While the adults may stay with the young up to 2 weeks after they leave the nest, the female may leave them when they are only a week old to start her next clutch. In such cases the male usually raises the young successfully by himself. Adults sometimes change mates between broods and one male has been known to feed the broods of two females simultaneously. All of which leaves many alternatives to explain the tragedy.

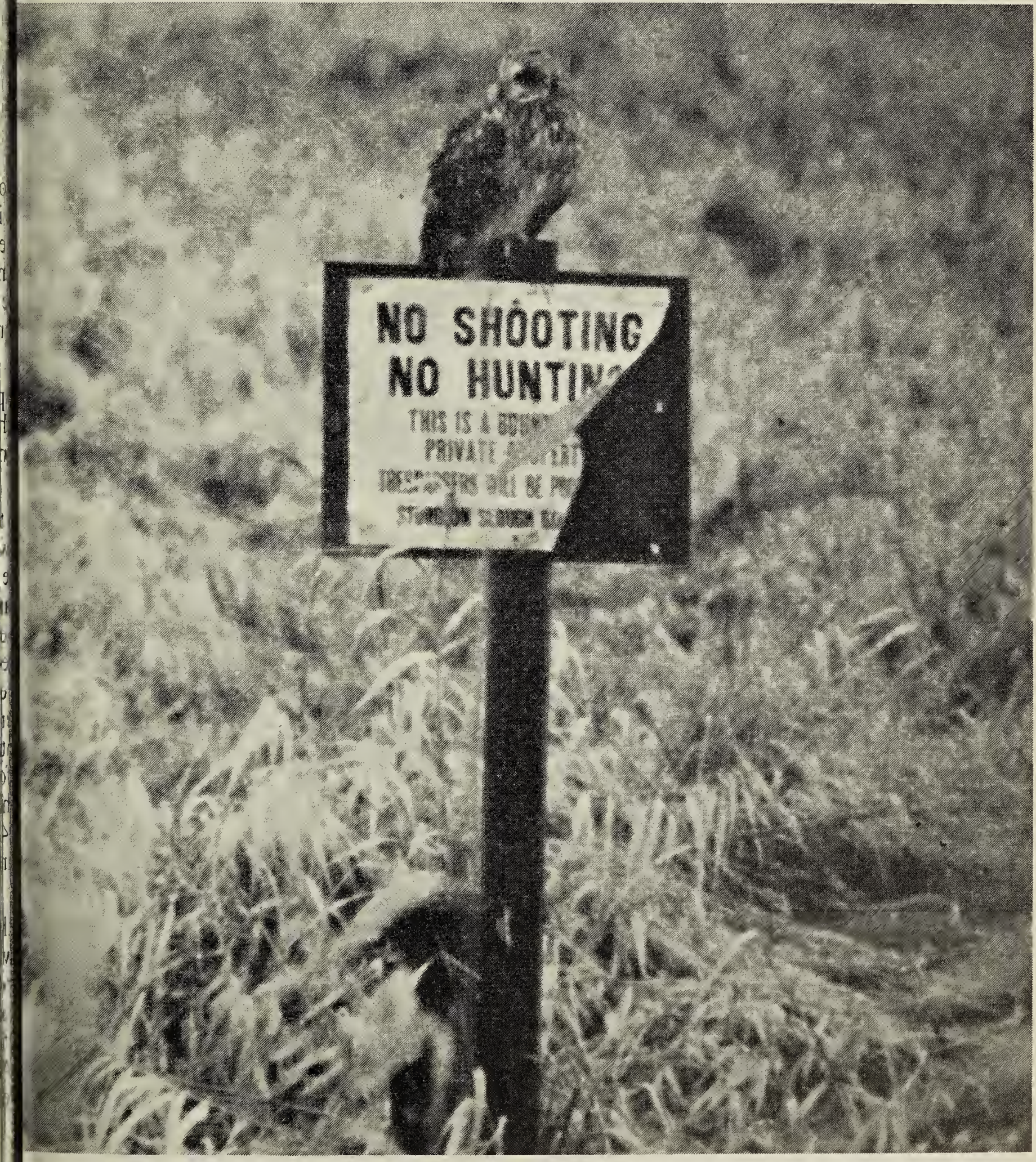

Wise old owl

Al Grass 